\title{
Tänapäeva vadja keel - kõnes ja kirjas
}

\section{Heinike Heinsoo}

doi:10.7592/PS/28-5heinsoo

Teesid: Artiklis vaadeldakse tänapäeva viimaste vadja keele kõnelejate keelt. Vadja keele kõnelejaid on vaid viis, aga viimase paarikümne aasta jooksul on vadja aktivistide tegevuse tulemusel hakatud looma kirjakeelt, mis nüüd on märkimisviisilt stabiliseerumas. Probleeme on Vaipoole kahe küla murdeerinevuste osas seisukoha võtmisega. 2003. aastast alates on kirjakeelega katsetatud ja avaldatud peamiselt muinasjututekste, mida on osaliselt "tõlgitud" Vaipoole murdesse. Vadjakeelseteks originaalteosteks võiks pidada 2010. aastal ilmunud kahte raamatut: "Vad'd'a päivüszikko 2011" ("Vadja kalender 2011) ja "Vad'd'a krazgõttavõ cirja" ("Vadja värvimisraamat"). Vadjalastele ja vadja külaelanikele mõeldud keelekursuste käigus selgus 2010. ja 2011. aastal, et praktikas läheb kirillitsas koolihariduse saanud eakatel õppijatel ladina tähestikul põhineva kirjaviisi omaksvõtmisega aega.

Märksõnad: Hääbuv keel, identiteet, kirjakeel ja murded, kirjakeele kujunemine, tõlkimine ja originaallooming.

\section{Vadja keel on hääbuv keel}

Traditsiooniliselt eristatakse vadja keeles nelja murret: idavadja, läänevadja, kukkusi ja kreevini murre. Läänevadja murret on jagatud omakorda kolme rühma: orko, mätši, ja Vaipoole. Tänapäeva viimased vadja keele kõnelejad elavad Vaipooles ja Vaipoolest lähtub ka vadja aktivistide tegevus. Vaipooles on kolm küla: 
Jõgõperä ja praegu administratiivselt üheks Luuditsa külaks liidetud Liivtšülä ja Luuditsa. Jõgõperä ja Liivtšülä-Luuditsa keel on erinev. Vaipooles on kuus vadja keele kõnelejat.

Zina Saveljeva (1938) on sündinud ja kasvanud Liivtšüläs, aga elab juba aastaid Jõgõperäl. Vaatamata sellele, et suurema osa oma elust on ta veetnud Jõgõperäl, kõneleb ta Liivtšülä-Luuditsa dialekti, sest tema lapsepõlv möödus Liivtšüläs. Zina on võimeline vadja teksti ladina tähtedega kirja panema. Emakeelse kõnelejana tajub ta häälikute pikkust ja kvaliteeti ilmselt paremini kui keegi teine ning suudab usaldusväärselt märkida, kas mõnes vormis on pikk või lühike vokaal või on lõpuvokaal sõnast hoopis kadunud.

Sergei Jefimovi (1954) vanemad olid vadjalased. Sergei etniliseks äratajaks on tema venelannast abikaasa Tatjana Jefimova, esimene Hõimurahvaste programmi Ilmapuu auhinna laureaat 2010. aastal. Auhind antakse soomeugrilist tegevust harrastavale aktivistile, kelle otsene töö pole selle tegevusega seotud. Jefimova algatusel on loodud ka vadja kultuuriseltsi kodulehel olev virtuaalne muuseum (http://vatland.ru/museum), millele on materjale vadja keeles sisse lugenud ka Sergei.

Nina Lenivenko (1935) on elanud suurema osa oma elust Jõgõperäl, kahekesi 1956. aastal sündinud tütre Tanjaga. Nina elab juba kümmekond aastat tööstuskeskuses Ust-Lugas ning tema suhtumine oma identiteeti on kahtlev ja kultuuripilt üsna venelik, kuna ta juhatas aastaid klubitööd ja tegeles vene kultuuri levitamisega. Hea laulja ja akordionimängijana eelistab ta vene estraadi.

Paša Kartašova (1928) elab Liivtšüläs, mis praegu on liidetud administratiivselt Luuditsa külaga. Tema keeles on palju isuripärast ning ka vene keel tahab sekka lipsata, aga õigele lainele saades on tema keel elav ja nünasirohke.

Nikolai Nesterov (1921) on vanim vadjalane. Kuulmise ja nägemisega on tal probleeme, aga vadjakeelne jutt tuleb endisel erusõjaväelasel hästi välja. Luuditsas on ta siiani veetnud oma eluõhtu soojema aja kevadest sügiseni. Tema on heaks näiteks selle kohta, kuidas Nõukogude armee pole suutnud inimest oma rahvust unustama panna. 
Ivan Georgijev (1928) on sündinud Luuditsas ja elab seal pidevalt. Ivani keel on vaba ja ta suudab üsna ladusalt tõlkida venekeelset teksti vadja keelde. Ivani isa Kiko Georgijev pajatas palju aastaid tagasi Paul Aristele hulgaliselt meremehejutte.

\section{Keelaksutuse muutus}

Lauri Kettunen arvas 1911. aastal oma esimese Vadjamaa reisi ajal, et Jõgõperä murre on vadja, isuri ja eesti keele segu (Kettunen 1945: 204).

1925. aastal kirjutas Dmitri Tsvetkov: "Usu keel on vadjalastele enamasti täiesti võõras. 60 või 80 aastat tagasi sai ainult $10 \%$ vadjalastest aru usu keelest (kiriku-slaavi keelest), ja 50\% - vene keelest. Aga aeg muutus /---/ Usu keel on praegu arusaadav suuremale osale, vene keelt räägivad kõik, välja arvatud kõige vanem põlv, kes oskab vene keelt halvemini, moonutades seda vadjapäraseks. /---/ Viimastel aegadel sündis assimileerumine ruttu igas harus. Toon näite: vadja majasse, kus veel kõneldakse vadja keelt, tuuakse noorik-isurlane, ja mis sünnib? Kõik perekonna liikmed, isegi vanad, hakkavad kõnelema isuri keelt." (Tsvetkov 1925: 42-43).

1942. aastal oli 11.-13. septembrini Vaipooles Ilmar Talve, kes kirjutas keele kohta: "Vadja keelt kõneldakse, aga mul jäi selline mulje, et see pole enam elav keel, rohkem kasutatakse isuri ja soome keelt. Vadjalased kasutavad ka ise omavahel kõneldes keelt, millel on tugev isuri mõju. Isegi lapsed räägivad isuri keelt, ehk oskavad ka vadja keelt (Talve 1990: 63-64).

Iseloomulik oligi suund sellele, et mitmed pered läksid üle isuri keelele, nt abielu kaudu. 1980. aastast mäletan peresid, kus üks õdedest pidas ennast vadjalaseks (Dunja Rodionova) ja teine õde (Tamara Borissova) isuriks.

1950. aastatel iseloomustas Paul Ariste vaipoole keelt kui segakeelt ja ütles, et vadja külades võib kohata inimesi, kes arvavad, et nad oskavad vabalt vadja keelt, aga tegelikult kõnelevad vaid vadja ja isuri segu ja mõnedel juhtudel vadja ja soome segakeelt. Tema arvates olid sellised keelesuhted väga tavalised Jõgõperäl, Liiv- 
tšüläs ja Luuditsas. Ariste väitis, et kõnealustes külades on segakeele kõnelemine niivõrd üldine, et ka isurite keeles on palju vadjapärasusi (Ariste 1960: 203-204).

Nihe on toimunud eelmise sajandi lõpus. Vadjalased enam isuri keelele üle ei lähe. Praeguse seisuga kõneleb enamik Vaipoole vadjalasi vene keelt. Probleeme tekitab viimastele vadjalastele murrete erinevus kahes külas - Jõgõperäl ja Liivtšülä-Luuditsas. Küsimus pole selles, et üksteist ei mõisteta, vaid selles, et kirjutatud keele puhul peaks võtma seisukoha, milline murdekuju saab selle aluseks.

\section{Ühiskondlik-poliitilised sanktsioonid keele elustamiseks}

Vadjalased on Venemaa väikesearvuline põlisrahvas. 2008. aasta 13. oktoobril võeti vadjalased vastu Vene Föderatsiooni väikesearvuliste põlisrahvaste nimekirja (Единый перечень коренных малочисленных народов России). 31. novembril 2008. aastal kirjutas kohalik leht sel puhul: "Selle väikese rahvakillu, keda on ainult 73 inimest, pingutuste tulemusel on säilitatud traditsioonid ja keel, antakse välja õpikuid ja lastele toimuvad, seni küll fakultatiivsed, emakeeletunnid..." Siin kõlab läbi tugev propagandistlik noot, mis suurrahvast kiidab ja ka väiksemat tähelepanust ilma ei jäta. Õpikuid ilmunud pole ja emakeeletunde ka pole, sest vadjakeelsete vanemate lapsi koolis ei ole. Ei saagi olla, sest praegu vadja keelt kõnelevate vadjalaste lapsed on täiskasvanud ja pole oma vanemate suust iial vadja keelt kuulnud. Pealegi ei ela nad enam kodukandis. Vanuse poolest võiksid Krakolje koolis käia nende lapsed, aga need käivad heal juhul suvel vanavanemate juures külas. 


\section{Rahvaloendused ja identiteet}

Dmitri Tsvetkov kirjutas 1925. aastal: "Kahjuks ei ole meil täpseid andmeid rahva arvu kohta. Ühede arvamiste järgi pole vadjalasi enam kui tuhat inimest, kuna aga teiste arvamise järgi on neid ligi kümmetuhat hinge... Õige küll, mõned nendest kõikuvatest arvudest nagu põhjeneksid täpsete andmete najal - Vene rahvalugemiste järele. Aga kui me võtame arvesse rahva hooletu ülestähendamise viisi pimedates maanurkades, mis tehtud oli vilumata inimeste poolt (isegi umbkaudselt, trobikondade viisi) ja ka selle asjaolu, et väga raske on rahvast liigitada keele põhjal, sest sageli ei tunnud üleskirjutajad rahva keelt ja otsustasid ainult enese "arvamise" või ebaselgete andmete järele, mis olid antud kolmandate isikute poolt... Kõige õigem rahva ülesmärkimisviis oleks muidugi isiklik järele pärimine perekonna isalt tema rahvuse kohta, aga praegu on meil võimata seda vahenditult korda saata" (Tsvetkov 1925: 39-40). Sama näitas 2002. aasta rahvaloendus - vadjalaste arvuks oli selle põhjal 73 ja keeleoskajaid lausa 10 korda rohkem. Vadja külades väitsid toonased vadja keele kõnelejad, et rahvaloendaja polnud nendeni jõudnudki. Rahvuseks pandi see, mis passis - venelane. Tegelik vadjalaste arv või siis õieti vadja keele kõnelejate arv, kellel oli kontakt oma keelekeskkonnaga, oli sel ajal ehk paarikümne kandis. Enne 2010. aasta oktoobris toimunud rahvaloendust küsitles ajakirja "Русский Репортер" ajakirjanik Jana Romanova viimaseid vadjalasi selles osas, mida nad rahvaloendusel oma rahvuse kohta kavatsevad öelda (Romanova 2010). Mõned väljavõtted: Tatjana Naumova (s 1941): "Nüüd muidugi kirjutan ennast vadjalasena üles, juttugi ei saa olla millestki muust”; Zina Saveljeva: "Muidugi vadjalane, aitab juba kartmisest"; Aleksander Borissov (1932-2012): "Mulle on see tegelikult ükskõik"; Taissa Mihhailova (1934), Nina Lenivenko, Nikolai Nesterov: "Venelane, nagu passis on." Siia sobib taas Tsvetkovi kommentaar: "Ja kui rahvaste määramise põhimõte ütleb, et rahvust ei või valida oma soovi järele, et teda ei või omandada äraõppimise kaudu vaid teatavasse rahvusesse kuuluvuse tunne kujuneb iseenesest, vallates inimhinge 
sügavuses sündivaid liikumisi, siis sammub see põhimõte vadjalaste juures viimasesse arengujärku, ikka vähem ja vähem valu sünnitades" (Tsvetkov 1925: 42).

\section{Kool ja vadja keel}

Jõgõperä koolide ajalugu pole täpsemalt uuritud, aga 20. sajandi alguses oli olemas igatahes külakool, veidi hiljem ka kihelkonnakool (Ernits 2009: 31).

Vadjalased on saanud kooliharidust mõningate väikeste eranditega ainult vene keeles (aastail 1936.-1937. õpetati Luuditsa koolis vadja lapsi isuri keeles). Dmitri Tsvetkov kirjutas 1925. aastal: "Täielikult hukka mõistes endise Vene keisririigi pärismaade poliitikat, pean ometi konstateerima, et vene koolide asutamine vadjalaste keskel ei tekitanud viimastes mingisugust vaenutunnet. Vadja rahvas pigemini tervitas neid sammusid, tundes oma isoleeritud olekus, et koolide kaudu võib sügavamini kreeka-katoliku usu müstikat tundma õppida ja selgemini aru saada omast suurest naabrist, kelle vaimline sugulus on ajaloo toode. Kool tungis samm-sammult rahva sekka. Aeg õigustas tema ebaloomulikkuse ja lõppude lõpuks sai nende meelsuse kohaks." (Tsvetkov 1925: 42-42). Krakolje keskkool (Jõgõperä kool) on pärast perestroikat olnud üsna aktiivselt tegev kohaliku põlisrahva keele ja kultuuri esiletoomisega. Lasteansambel on aastaid muutuvas koosseisus laulnud vadja laule, Jõgõperä kooli juures õpetas 1990. aastate keskel vadja keelt lingvist Mehmet Muslimov, kes kaitses kandidaadiväitekirja Lääne-Ingeri keelekontaktide alal. Muslimovil on Internetis ka viis vadja keele tundi (http://www.vatland.ru).

Muslimovit abistasid koolilastega tegelemisel vadjalased Zina Saveljeva ja Tatjana Prokopenko (1935-2006). Vahel lõi kaasa ka vadja aktivist Tatjana Jefimova. Igatahes on nende tundide tulemusel vadja lasteansamblil "Linnut" ("Pääskölinnut") olnud kergem ära õppida vadjakeelseid laule ja väikeseid sketše. Käesoleval aastatuhandel on õpetus olnud juhuslik. 


\section{Emakeelsed õpetlased ja kirjakeel}

1932-1937 eksisteeris ladina tähestikul põhinev isuri kirjakeel, mida õpetati ka koolides. Isuri kirjakeele lõi Väino J. Junus, kes oli ilmselt soomlane. Junus sündis 1905. aastal Pokisenpurskaja külas ja lasti maha 15.11.(1.11?)1937. aastal. Junus töötas Leningradi Ajaloo ja Lingvistika Instituudis dotsendina ja valmistas ette isurikeelset õppematerjali (Mirenkov 2002: 208). Õppematerjal oli mõeldud nii Soikkola kui ka Alam-Lauga murde kõnelejatele. 1932. aastast 1937. aastani valmis 32 õpikut. Mõnede järgi õppisid ka Luuditsa algkooli õpilased.

Ainus vadja haritlane Dmitri Tsvetkov sündis 30.08 .1890 Jõgõperäs ja suri 26.08.1930 Narvas. Tsvetkovi kohta on põhjaliku ja huvitava raamatu kirjutanud Enn Ernits (2009). Tartus professoriametit pidava Lauri Kettuneni kutsel tuli Tsvetkov Tartu Ülikooli õppima. Emakeele Seltsi stipendiaadina valmis tal vadja-eesti sõnaraamatu käsikiri (Tsvetkov 1995), grammatika oli tal juba varem valmis (Tsvetkov 2008). Tsvetkovist ei saanud votoloogi, vaid slavist ja kooliõpetaja Alajõe koolis, ta kaotas huvi vadjalaste ja vadja keele arendamise vastu. Tema grammatikat pole tänapäeval õpetuses võimalik kasutada; sõnaraamat on väärtuslik sõnavarakogu.

\section{Kas vadja keelel on kirjakeelt?}

\section{Murded}

Kolme Vaipoole küla keel erineb omavahel ennekõike lõpuvokaalide poolest (Markus, Rožanskyi 2011: 45). Trükis ilmunud grammatikad tuginevad läänevadja Kattila (mätši) küla keelele. Markuse ja Rožanskiy 2011 aastal ilmunud “Современный водсий язык” on põhjalik ülevaade tänapäeva vadja keelest, s.o Jõgõperä ja Liivtšülä-Luuditsa dialektist. 


\section{Uurijate kirjapanekud}

Esimesed vadja keele kirjapanekud on pärit 1783. aastast. 19. sajandi vältel panid vadja keelt kirja asjaarmastajad, folkloristid, lingvistid. Kirjapanekute tase ja huvid muutusid läbi aegade (Heinsoo 2004, Heinsoo, Kuusk 2011). 1909. aastal kasutas E. N. Setälä (Posti, Suhonen 1964) vadja keele ülesmärkimiseks soome-ugri teaduslikku transkriptsiooni (FUT). Sellest ajast alates on seda vadja keele ülesmärkimiseks suurema või väiksema foneetilise täpsusega kasutanud enamik lingviste. Niisiis on üleskirjutatud teksti palju, aga tavalugejale, eriti kirillitsas lugema ja kirjutama õppinud vadjalastele on nende lugemine keeruline. Seda enam, et venekeelse tõlkega tekstid praktiliselt puuduvad.

\section{Kirjakeele sünd}

Tänapäeval kõneldakse vadja keelt ainult Vaipooles ja seetõttu peaks kirjakeel põhinema ka sellel murdel. Tõsi, murre erineb kahes külarühmas. Huvitavad on O. A. F. Mustoneni kirjapanekutd Jõgõperält (Mustonen 1883), mida võiks täielikult tänapäeva vadja kirjakeeleks lugeda. Transkriptsioonimärgid praktiliselt puuduvad, tekst on selge ja loetav, ehkki keeles on muidugi 120 aasta jooksul toimunud muutusi (Mustonen 1883: 154).

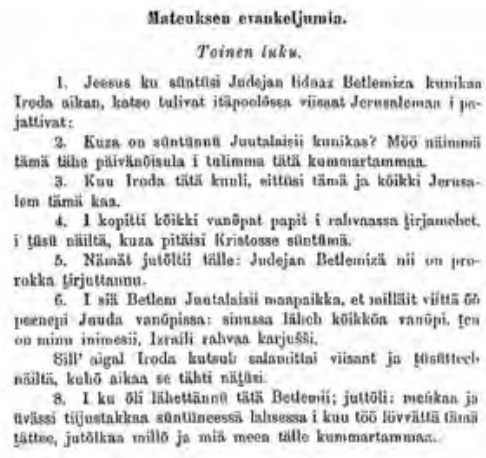

Matteuse evangeelium. 
Vadja haritlane Dmitri Tsvetkov lõi omapärase kirjaviisi kirillitsa baasil, lisades häälikute $\ddot{a}, \ddot{o}, \ddot{u}$ tähistamiseks vene tähtedele peale kaks täppi (Tsvetkov 2008). Vadja keele sõnaraamat kasutab vadja keele ülesmärkimiseks praktiliselt eesti kirjakeelt, aga kajastab vajaliku täpsusega eri murretele iseloomulikke jooni (Tsvetkov 2008: 30, 3):

Enn Ernits nimetab vadja kirjakeele loojaks Sankt-Peterburgi lingvisti Mehmet Muslimovit (Ernits (2006, 2010b), kes 2002/2003. aastal pani Internetis üles viis õppetundi (http://www.vadjamaa. narod.ru/language/language.html). Tema loodud kirjaviisis avaldati ka 2003. ja 2004. aastal esimesed raamatud. Trükis ilmusid "Vađđa kaazgõt" ("Vadja muinasjutud"). Muinasjutud põhinevad Paul Ariste ja Julius Mägiste kirjapanekutel ja erinevuseks eri aastatel ilmunud muinasjuturaamatute vahel on see, et 2003. aasta väljaandes esitatakse algupärane, uurijate kirjapandud murdekuju, aga 2004. aastal on tekstid "tõlgitud" Jõgõperä murdesse. Teiste murrete tekste on Jõgõperä murdesse pannud ka Dmitri Tsvetkov. Ta abistas Lauri Kettuneni tema üleskirjutuste ülevaatamisel ja “tõlkis" Jõgõperä murdesse 7 idavadja teksti (Kettunen, Posti 1932: 118-144). Tsvetkovi kirjapanek oli teaduslikus transkriptsioonis.

Ülesmärkimisviis on pidevalt muutunud ja sellest on kirjutanud põhjalikult Enn Ernits (2006, 2010b). Vadjakeelne esialgne alfabeet, lühitõlkeid ja temaatilisi sõnaloendeid on ilmunud ka kohalike aktivistide poolt välja antud ajalehes "Maavätši” (hakkas ilmuma 2005. aastal), mille peaeesmärk on tutvustada Vaipooles ja selle ümbruses toimuvat, vadja kultuurielu ja kodulugu.

2009. aastal ilmus Olga Konkova toimetatud "Vad'd'aa rahvaa jutud ja kaazgad" (Konkova 2009), milles muinasjuttudel on venekeelne tõlge ja tekste on üritatud panna Muslimovi loodud kirjakeelde ja ka Jõgõperä murdesse. Enn Ernits tunnustabki kasutatava kirjaviisi kirjakeeleks: "Kõik vadja rahvaluule tekstid on avaldatud kirjakeeles, kusjuures murde eripärad on säilinud" (Ernits 2010a: 858). Raamat on kaunilt illustreeritud ja meeleolukas. 


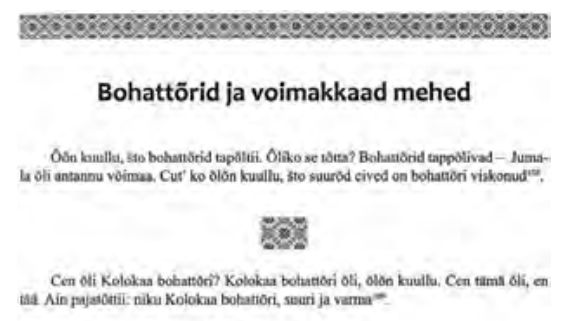

78:

Bohattõrid. (Konkova 2009: 34)

Vadja kirjakeele üheks nõrkuseks oli kaua vadja keele kõige iseloomulikuma joone $t \check{s}(\check{c})$ märkimine $c$-grafeemiga. Probleemiks oli väidetavalt grafeemimärgi č tülikus ja $c$ kasuks esitatud argument oli suhteliselt lihtne - kel vaja, see teab nagunii, mis häälikut $c$-ga märgitakse. Soomepärane $y$-vokaalimärgi kasutamine läheb vokaalimärkimise süsteemist välja, sest kasutusel on eesti kirjakeele $\tilde{o}$-grafeem (Kuznetsova 2010, Jefimova 2010). Seitsmeköiteline "Vadja keele sõnaraamat" kasutab eesti alfabeedil põhinevat lihtsustatud märkimisviisi (1990-2011). Lahknevused kõiki murdeid kajastava hiiglasliku sõnaraamatu ja kohaliku kirjaviisi vahel segavad kindlasti sõnaraamatu kasutamist. Nüüd viimasena vadja kodulehel (http://vatland.ru./lang/index.php) avaldatud alfabeet on samasugune, nagu seda kasutab vadja keele sõnaraamat.

\section{Tõlkimine ja algupärane vadjakeelne looming}

\section{Tõlkimine}

Enamik vadja tekste on tõlgitud tekstid. O. A. F. Mustonen avaldas vadja keeles Matteuse evangeeliumi 2.-6. peatüki, mille tõlkija pole teada, aga keel on Vaipoole, täpsemalt - Jõgõperä keel. Ehkki kirjapanek, on see väga arusaadav ka tavalugejale, kes vadja keelt oskab. Ühest murdest teise "tõlkimist" on esinenud rohkem. Näi- 
teks Dmitri Tsvetkov tõlkis Kettuneni idamurde tekste Jõgõperä murdesse.

Ainsaks kirjanduslikuks tõlkeks võib pidada tema Tšehhovi novelli "Vanka" tõlget (Kettunen, Posti 1932: 144-152). See on heatasemeline, sõnavara on rikas ja lauseehituses pole originaaltekstisse klammerdutud. Kogu tõlkes kajastub tõlkija hea vene ja vadja keele oskus ning järjekindlus enda loodud lõpukaolise Jõgõperä keelenormi kasutamisel.

Tavaliselt on enamik tõlkeid, mida vadja keele oskajad teevad, muidugi suulised, mõeldud küsitlejale-lingvistile, kes teksti kirja paneb. Vahel on tekst loodud enda tarbeks. Huvitav on Tatjana Prokopenko meieisapalve tõlge, mille ta 2003. aasta külapeol ette kandis. Tõlget võib kuulata Taisto Raudalaineni ja Ergo Västriku filmist "Ja päästa meid ära kurjast” (60 min, ETV 2004).

Tõlke kohta ütleb ta Tamara Borissovale: miä izze vääntäzin 'ma ise tõlkisin':

Anna meille leipää süümä vart i prosti meild meije võlgad kui mü prostimme meije võlgad inemizille. Võta meilt pois tak iskušen' je i oo meije poolõss paganuzõs.

Tekst oli paberil kirjas ja ka ette valmistatud, aga Tatjana ei lugenud seda maha.

Tõlkimine ongi praegu kõige suurem probleem. Vadja keele sõnaraamatus on enamasti ka venekeelsed tõlked, aga nende leidmine pole kerge, sest selleks peab läbi lugema sõnaartikli eestikeelese osa. Vene-vadja sõnaraamat siiani puudub, ehkki Eesti Keele Instituudil on see kavas välja anda. Napi keeloskusega entusiastidel pole kusagilt sõnu otsida. Internetis avaldatud sõnaraamatud on viletsad (nt Tšernjavski, Vitali 2005. "Vad'd'a tšeeli (Izeõpõttaja)", 2000 sõna; http://vod.org.ua). Tatjana Jefimova eestvedamisel tegeletaksegi eri tekstide tõlkimisega vene keelde. Tatjana Jefimova kirjutas 12.09.2010, et nad tõlkisid neli muinasjuttu ja kavatsevad Anu Hvatova rahvalaule tõlkida. Üht-teist on ka kodulehel vatland.ru, aga kirillitsa kasutamine seal vadja keele kirjapanemisel on üllatav (nt “Куй мия казалин канайне”). Teisalt ehk polegi see nii üllatav, sest kodulehe lugejad, kes elavad Venemaal, mõistavad kirillitsas 
teksti paremini. Seega tekibki küsimus - kirjakeel nagu oleks olemas, aga kasutajad...

\section{Algupärane looming}

Algupäraseks võib pidada Jekaterina Kuznetsova 2010. aastal ilmunud värvimisraamatut "Vad'd'a krazgõttavõ cirja" (Kuznetsova, Muslimov 2010) ja Tatjana Jefimova toimetatud vadja kalendrit "Vad'd'a päivüzikko 2011" (Jefimova 2010). Värviraamatu lõpus on alfabeet, kuhu kuuluvad ka palataliseeritud sibilandid, r ja t', afrikaati $\check{c} / t \check{s}$ märgib $c$ ja $c$-d $t s$. Raamatus rändab pääsuke üheteistkümnel lehel ja seda, mida ta lennul näeb, iseloomustavad lihtsad laused. Esilehel on veel kolm sissejuhatavat lauset: $\mathrm{Vad}^{\prime} \mathrm{d}^{\prime} a-$ maa on maa Soomõ Lahõ lõunad rannõz. Se on kõvi lusti. Kassõnn ammuzõlt aigalt eletä vad'd'alaizõd. 'Vadjamaa on maa Soome lahe lõunarannal. See on väga ilus. Siin elavad ammusest ajast vadjalased.'

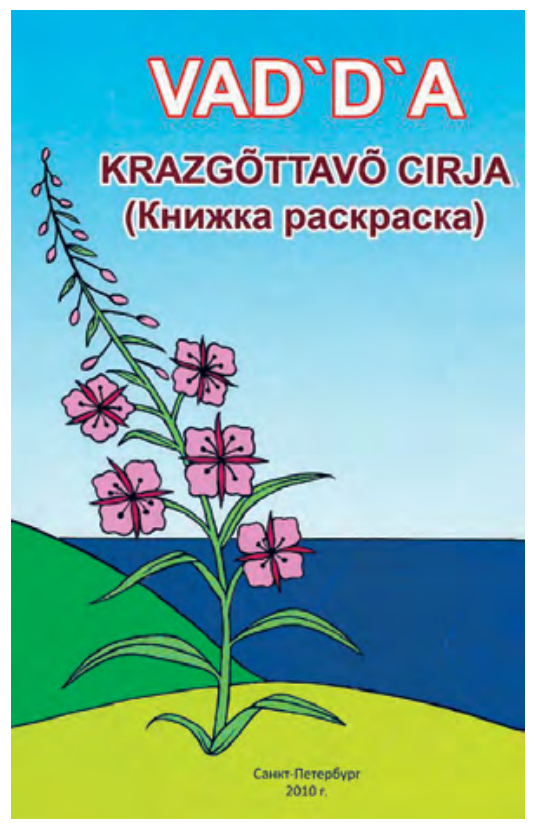

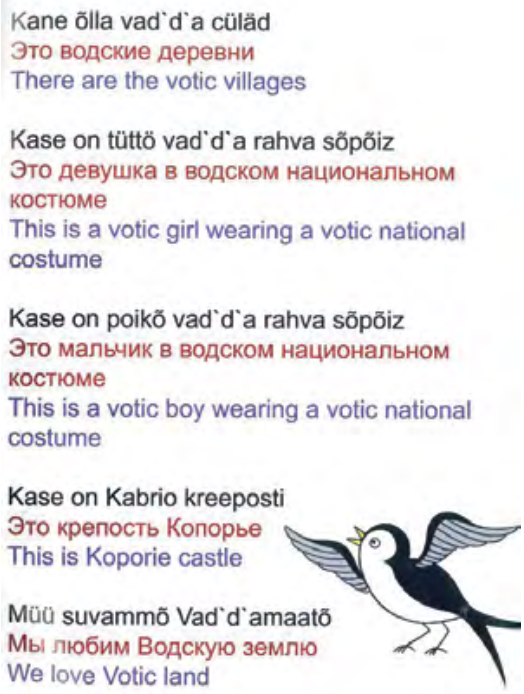


Tekst on järjekindlalt Jõgõperä keelekasutusele iseloomulik ja paistab silma purismiga. Näiteks lauses Vad'd'a rahva loomõ on karu on sõna loomõ selgelt eesti laen, mis sõnaraamatus esineb märkega Tsv, s.o ainult D. Tsvetkovilt kirja pandud. Autor pole tahtnud kasutada vene laenu zveeri. Ka mõjub eestipärasusena sõna rahvas (gen. rahva) kasutus. Ilmselt oleks parem vad'd'a väe. Lõpus esinevad kõik raamatus olnud laused ka vene- ja ingliskeelsete tõlgetega.

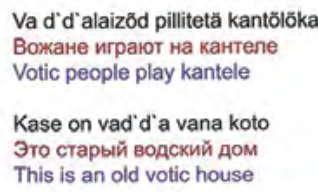

Tekstinäiteid Vadja värviraamatust.

Tatjana Jefimova koostatud kalender "Vad'd'a päivüzikko" on vene- ja vadjakeelne. Pühade valimisel on abiks olnud Paul Ariste "Vadja rahvakalender" (Ariste 1969). Nii vene- kui vadjakeelse väljaande keeleline korrektor on Mehmet Muslimov. Kalendris esineb head sõnaloomet. See kajastub juba sõnas päivüzikko, mida "Vadja keele sõnaraamatus" pole. Originaalteksti keel on enamasti Liivtšülä-Luuditsa murdele iseloomulik, nt tuhkapäive, tõinpäive, kõlmõspäive... 'esmaspäev, teisipäev, kolmapäev'. Esmaspäeva tähistav sõna tuhkapäive tekitab praegustes kõnelejates segadust ja "Vadja keele sõnaraamat" (1990: 212) esitabki Vaipooles sõnakuju esimespäivä; tuhkapäivä oli iseloomulik orko-murderühma küladele. Kohati esineb ka ka Jõgõperäle iseloomulikku lõpukaolisust. Ariste kalendriraamatu tsitaadid on säilitanud originaalkuju, nt on septembris Spiridonipäeva (spirka) iseloomustus Lempolast kirja pandud (Ariste 1969: 141), kalendritekst jäljendab seda vigaselt. Kalendris on ära toodud ka 13 . oktoober - vad'd'a rahva päive 
'vadja rahva päev' - see on päev, mil vadjalased lülitati Venamaa väikesearvuliste põlisrahvaste nimistusse. Hulgaliselt esineb huvitavaid pilte nii tänapäeva vadjalastest, vadjalastele olulistest iskutest (Paul Ariste Helsingi ülikooli audoktoripromotsioonil veebruarikuus, Dmitri Tsvetkov oma sünnikuul augustis), museoloogilistest esemetest, vanu arhiivifotosid küladest jne. Koostajad on järginud teaduslikku täpsust illustratsioonide kommenteerimisel. Tõlgetes on mõningaid vigu. Igatahes on tegu omamoodi teatmeteosega, mis teemaga tuttavate inimeste südame soojaks teeb.

Ferenc Válóczy ingliskeelsel kodulehel on vadjakeelsed tekstid ja luuletõlked, aga kuna need on kirillitsas, on nende kirjaviisi kohta raske midagi arvata (http://www.geocities.com/Vienna/3259/ index.html).

Huvitavaks katseks on Enn Ernitsa vadjakeelne luuletus (Ernits 2006a : 219):

Uni-lintu lensi kaukaalt, Liblikas see lendas kaugelt, Entši-lintu manalassa. Hingelind see manalast.

Minuu Mar'a aika koollu, Minu Maarja ammu koolnud,

Tuli-kutsub ómaa meessä. Tuli - kutsub oma meest.

\section{Vadja keele lugemise ja kirjutamise probleemidest praktikas}

\section{Keelekursused}

2010. ja 2011. aasta suvel korraldas Heinike Heinsoo Jõgõperäl neljapäevased vadja keele kurused "Vunukassa baabuškassaa" ("Lapselapsest vanaemani”). Osalejaid oli paarikümne ümber. Rohkem olid esindatud vanaemad, lapselapsi oli vähe ja nende pealehakkamine tagasihoidlikum. Osales ka kolm vadja keele kõnelejat. Mõnel osalejal oli teatud passiivne vadja keele oskus olemas, nt Sergei Jefimovi õde Nina Vittonk, Taissa Mihhailova, Tatjana Naumova said üllatavalt hästi aru vanasõnadest ja muust tekstist. Kursusi on kajastanud Inkerin Kulttuuriseura väljaanne "Inkerikot ja vatja- 
laiset 2010” (Ifolor), kus tekstid ja fotod on pärit Aune Kämäräinenilt, samuti tema kirjutised ajakirjas "Inkerin Kulttuurikanava" (Kämäräinen 2010, 2011).

Kursustel kerkis lugemise ja kirjutamise probleem teravalt esile. Esimesel kursusel 2010. aasta suvel oli ópetus liiga klassikaline ja eeldas üsna palju kirjutatud teksti kasutamist ja ka ise kirjutamist. Mõlemad tekitasid raskusi. Siiski läks üllatavalt hästi rahvalaulutekstide lugemine ja laulmine, samuti lühemad tekstijupid, nt vanasõnad ja mõistatused. Järgmistel kursustel 2011. aastal oligi

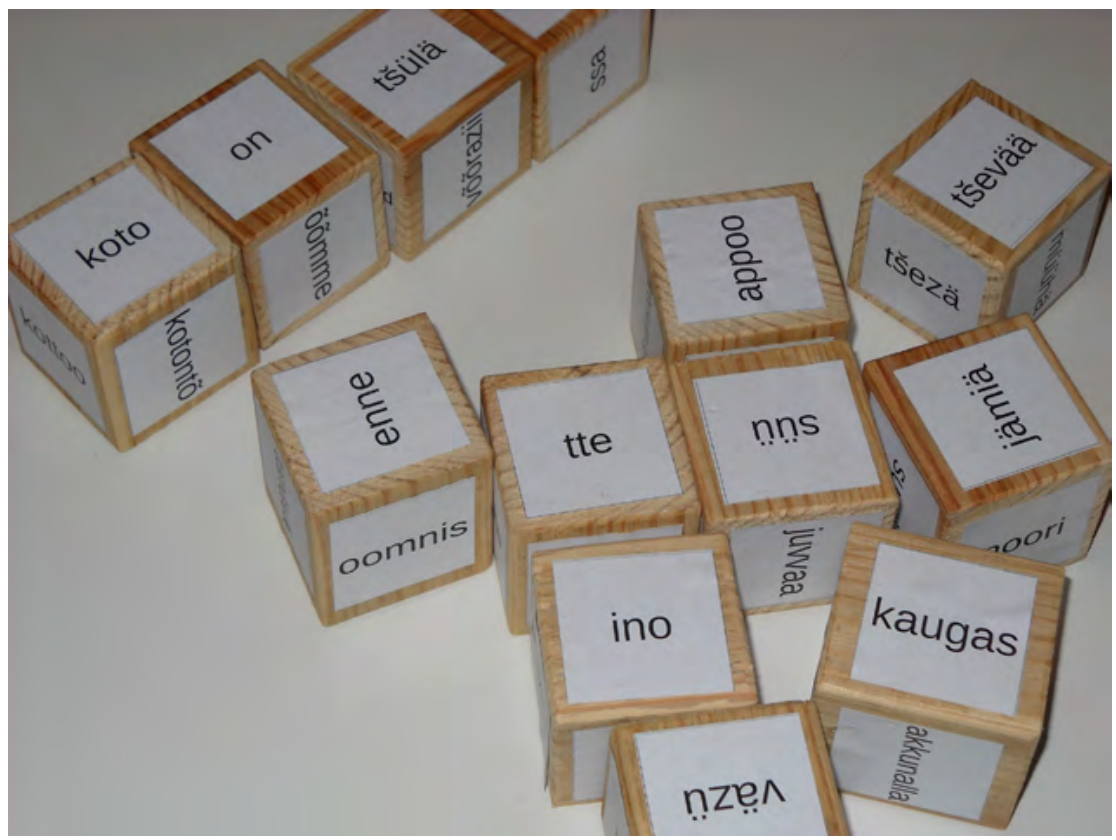

Sõna- ja morfeemikuubikuid oli 2 komplekti, kummaski 36 klotsi. Võistkonnad panid kokku lauseid.

vadja keeles kirjutamine viidud miinimumini, kuna kogu materjal oli trükitud kujul olemas. Lisaks soodustas õppimist tugev mänguline element - morfeemikuubikud, värvilised kaardid inimeste 


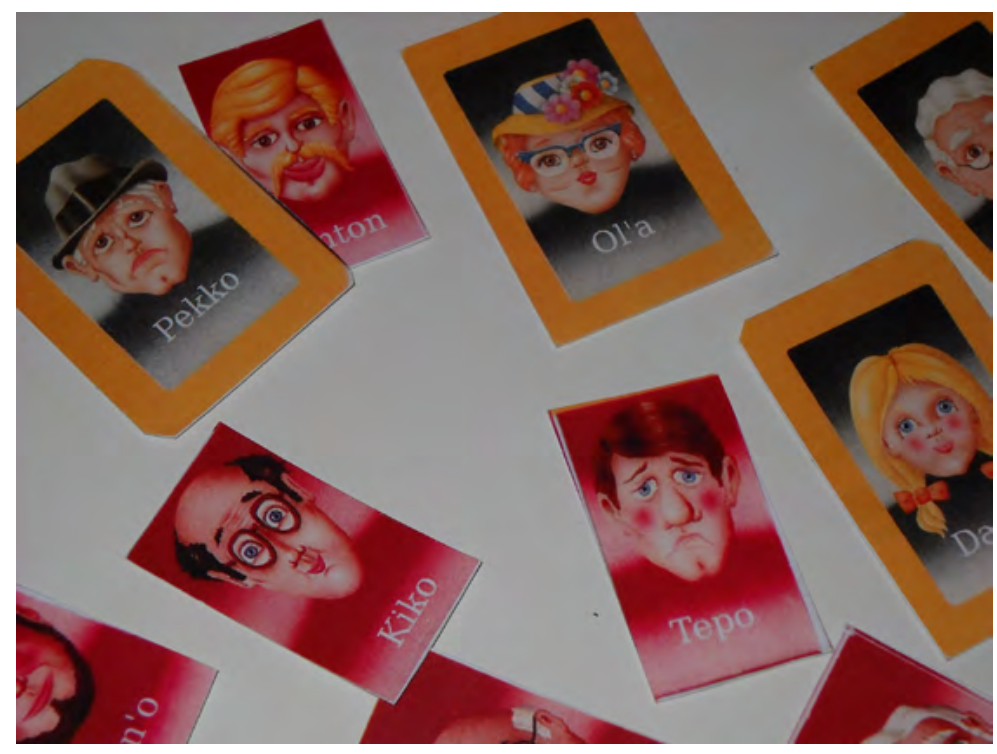

Mängijad pidid vastasmängija kirjelduse järgi ära arvama, kelle pilt on tema käes oleval kaardil.

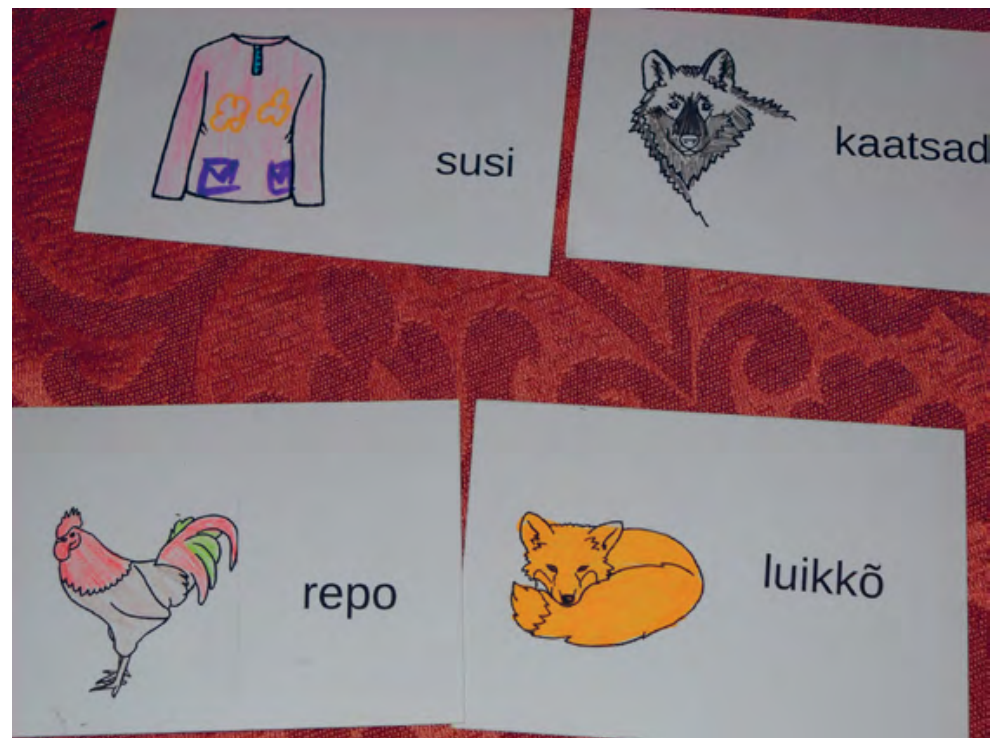

Sõna- ja pildilotos tuli piltide ja sõnadega kaardid õigesti kokku viia. 
kirjeldamiseks ja äraarvamiseks, tükkideks lõigatud mõistatused, valmis sõnasedelid, sõna- ja pildilotod jne.

Aga ise vadjakeelset teksti üles kirjutama olid võimelised vaid Zina Saveljeva, noor isuri taustaga Soikkola koduloomuuseumi töötaja Nikita Djatškov ja veidi ka Nina Jefimova. Kasutatud tekstid olid järjekindlalt vadja keele sõnaraamatus kasutatavas kirjaviisis ja see on nüüd ka vilja kandnud, sest kodulehele ongi ilmunud uus alfabeet. Seega - peale suuri sünnitusvalusid on praegune vadja kirjakeel jõudnudki sellisele kujule, nagu seda kasutab alates 1990. aastast ilmunud sõnaraamat. Näib, et jalgratas on taasleiutatud.

Igatahes toimisid keelekursusel hästi mängud, kus ise polnud vaja midagi kirjutada.

\section{Tarbeteksti loomine}

2011. aasta novembris paigutati helifailina vadja veebilehele vatland.ru Sergei Jefimovi (s 1954) vadjakeelne suuline tekst "Virtuaalne jalutuskäik Luuditsas". Jefimov kommenteerib vanu fotosid ja kõneleb sellest, mis vanasti külas oli: http://vatland.ru/toponim/ vm/luzici.php.

Tekst on algupäraselt olnud venekeelne, esitaja on selle vadja keelde tõlkinud ja endale vadja keeles kirillitsat kasutades kirja pannud. Tema loetud teksti vead tulenevad ennekõike sellest, et ta pole tõlgitud teksti osanud üles märkida ega hiljem ülesmärgitut maha lugeda. Tatjana Jefimova sõnul ongi selliseid ülestähendusi raske mõista. Seetõttu esineb tekstis üllatavalt palju algelisi astmevahelduse vigu, valet käändekasutust ja muid selliseid üsna primitiivseid möödapanekuid, mida Jefimov tavalises kõnes ei teeks. Jefimov on osalenud mõlemal vadja keele kursusel, aga tema osalus tundus olevat üsna passiivne.

Küsitluste puhul olen saanud omakäelisi vadjakeelseid kirjapanekuid Zina Saveljevalt. Saveljevat on segadusse ajanud vadja kirjakeeles toimunud muutused. Kohusetundliku inimesena, kes on ka Eestis kõrgkoolis õppinud, on ta proovinud muutustega kaasas 
käia. Ja see on teda endas kahtlema pannud ja segadusse ajanud. Zina Saveljeva konsulteeris "Uurali keelte sõnastiku" vadja osa. Nüüd on ka see teos Vaipoole murdes ja sedagi võiks tarbetekstiks pidada (UKS 2004, 2007). Sõnaraamatu sisu paneb külakeelt kõnelevaid inimesi kohati muigama ja paljud konventsionaalsused kõlavad vadja keeles kunstlikult. Esimese osa puhul oli konsultandiks Tatjana Prokopenko (1935-2006).

Originaaltekstiks võib pidada Zina Saveljeva jõulukaarti.

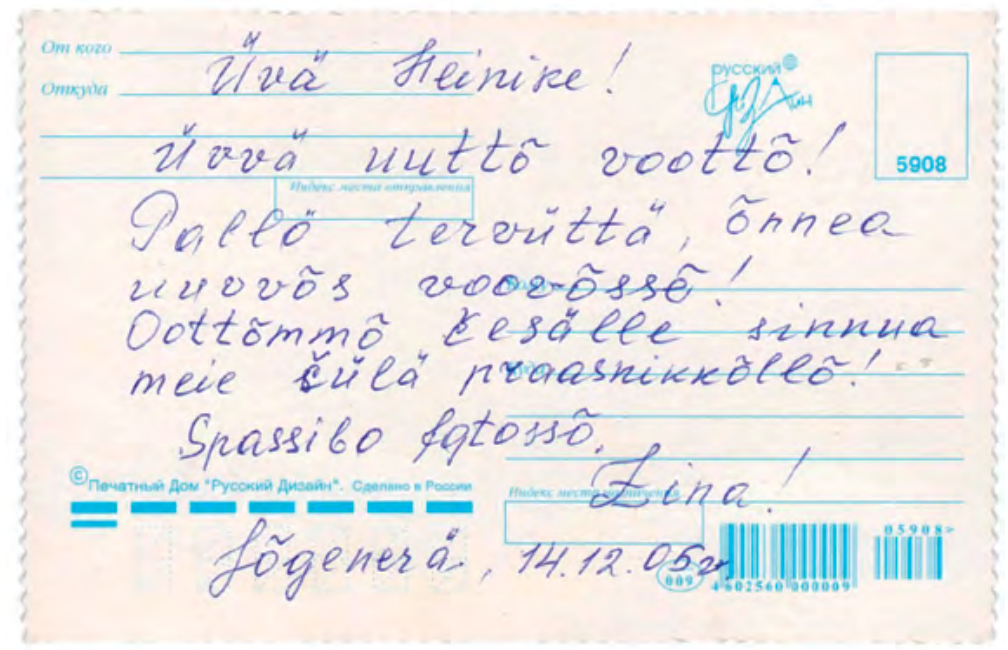

Zina kirjaviis oli juba 2005. aastal selline, nagu praegu kasutusele on tulemas. Nii näib, et kirjakeel hakkab ilmet võtma, aga kas vadjalaste hulgas selle kasutajaid leidub, on kahtlane. Siiski on tore, et valmis tekstide lugemine õnnestub vadja keele kõnelejatel üsna hästi. Kirjakeele juurdumisele aitab kaasa vene-vadja sõnaraamatu ilmumine. Loodetavasti soodustab sõnaraamat ka vadjakeelse originaalloomingu teket. Loomulikult oleks aeg ka koostada algõpetuse tarvis lugemik. Ja kindlasti tuleks langetada otsus nt sõnalõpu vokaalide suhtes. Jõgõperäs on sageli sõna lõpust $a / \ddot{a}$ kadunud, Liivtšülä-Luuditsa dialektis esineb aga sel puhul õ/e. Keelekursus- 
tel oli sel teemal sageli ütlemist ja taas tuli selgitada, et kirjakeel on kokkuleppeline keel ega ole mitte kellegi emakeeleks.

Viimastel aastatel on vadja liikumises agaralt kaasa löönud Soikkola isuri muuseumis töötav Nikita Djatškov (s 1988). Mõned näited kirjavahetusest käesoleva loo autoriga (kirjavahetuse algatajaks oli Djatškov):

5.03.2012

Tere, Heinike!

Jõgõperälaizõd cyzytti minnua sillõõ jutõlla, jott janvarikuuz Ol’o Borisov kooli väl'l'ää. Täll õli kahõsacümment vootta. Tätä avvõttii Jõgõperä kalmoillõõ. Mejjee nõmad (Marina, Zina täti, Vera täti) saatõtaa sillõõ tervyttä. Kui teill d’elad õllaa? Kui tyy elätt?

Nikita Djackov

'Jõgõperälased palusid mul sulle öelda, et jaanuaris suri ära $\mathrm{Ol}^{\prime}$ o Borissov. Ta oli 80-aastane. Ta maeti Jõgõperä surnuaeda. Meie omad (Marina, Zina-tädi, Vera-tädi) saadavad sulle tervisi. Kuidas teil asjad on? Kuidas te elate?'

Kirjaviis järgib Muslimovi varasemaid kirjapanekuid, lõpuvokaalide osas on enamasti kasutusel Jõgõperäle iseloomulik variant. Vastasin kirjutajale, üritades kasutada järjekindlalt Liivtšülä-Luuditsa murret. Nikita järgmine kiri (6.03.12) on selline:

$\mathrm{Ni}$, kase kal'endar' nii kõvassi suuri, miä cüsüzin heilte tehä peenepi, no vasattii što nõissa tecemä niku i menn voottõ. Se eb õõ yvä, no mitä tehä!? Võib õlla tulõval leeb parõpi.

Se on üvä veesti, miä vähäze toož õpõtan lahsii ižoraa ceelte Viistinaz, kui tunnõn da võin. Kutsuttii Jaamaasõõ, da seel' toož õli ühs zanjatije ižoraa ceelel. A Jõgõperä škouluz nüt jõka esimes' -päivä laulamm vad'd'aa ceelel lahsiikaa da proovammõ õppõssa vad'd'aa ceelte. Oottõõmmõ teitä!Anna antõssi jott mill on nii pal'l'o ošibkoi.

Mikitta. 
Siin vastuses on jutt isuri 2012. aasta kalendrist ("Ižorin kalendar' 2012").

'Nii, see kalender (on) nii väga suur, mina palusin neil teha väiksem, aga vastati, et hakatakse tegema nagu eelmisel aastal. See ei ole hea, aga mida teha. Võib-olla järgmisel tuleb parem. See on hea teade, ma ka veidi õpetan lastele isuri keelt Viistinas, nagu oskan ja suudan. Kutsuti Jaamasse (Kingisseppa), ja seal on ka üks tund isuri keeles. Aga Jõgõperä koolis laulame nüüd igal esmaspäeval vadja keeles lastega ja proovime õppida vadja keelt. Ootame teid! Anna andeks, et mul on palju vigu.'

Djatškovi keelekasutus muutus teises kirjas Liivtšülä-Luuditsa murde sarnasemaks, aga ta hoidis kinni $c$ ja $y$-grafeemi kasutusest. Tõsi, viimasest mitte alati. Seega võib öelda, et vadja kirjakeel hakkab kasutust saama ja üksteisemõistmine oli täielik.

Enda kohta kirjutab Nikita Djatškov (12.03.12):

A mitä võib cirjuttaa enesse?! Miä süntüzin Petteriz 1988 vooõz. Da õppõzin Petteriz. Vanõpad eletää seel'. A kõnz miä lõpetin õppõssa universitetaz, minnua kutsuttii tehhä tüüt Viistina muzejaa. Vot i menin Petterisse vällää da nõizin elämää Jõgõperää cüläz minuu ämmäl. Miä en õõ vad'd'alain. Võib õll minuu vanad sukulaizõd õltii vad'd'alaizõd Jõgõperälte, sitä miä en tää, no rohkõpi kõik õllaa soikkolaizõd (ižorid) da venäläized. Taattõ on ižori Jõgõperälte, a emä on venäläin Petterisse. Millõõ näüttiib ellää cüläz, siin saab veel pajattaa ja läätä. $\mathrm{Da}$ cüläz eläd niku voolil.

'Aga mida võib kirjutada endast?! Ma sündisin Petteris (Peterburis) 1988. aastal. Ja õppisin Peterburis. Vanemad elavad seal. Aga kui ma lõpetasin ülikoolis õppimise, kutsuti mind tegema tööd Viistina muuseumisse. Vaat ja läksingi Petterist (Peterburist) ära ja hakkasin elama Jõgõperä külas oma vanaema juures. Ma ei ole vadjalane. Võib-olla minu sugulased olid vadjalased Jõgõperält, seda ma ei tea, aga rohkem on kõik soikkolalased (isurid) ja venelased. Isa on isur Jõgõperält, aga ema on venelane Petterist (Peter- 
burist). Mulle meeldib elada külas, siin saab veel vadja ja isuri keelt kõnelda. Ja külas elad nagu vabalt.'

Afrikaadi märkimise kohta ütleb ta: Nii, mill ôllaa mokomad bukvõd, no müü kassin cirjutammõ "tš" - niku "c". En tää, õikassi kase vai eb õ õ, no minnua ópõtattii cirjuttaa nii viisii. 'Nii, mul on

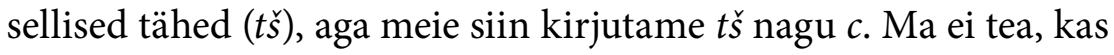
see (on) õigesti või ei ole, aga mind õpetati niimoodi kirjutama.' Nikita Djatškov käis Muslimovi juures vadja keele eratunde võtmas.

Seega kirjakeel toimib - vaatamata teatud ühtlustamisvajadusele. 1967. aastal kirjutas Ariste oma päevikus, et Luuditsas ja Liivtšüläs kõneldakse igas majas läänemeresoome keelt ehk vadja keelt, isuri mõjudega vadja keelt või siis vadja mõjudega isuri keelt (VP 2005: 97). Praegu üheski majas vadja keelt ei kõnelda, sest üksi pole mõtet rääkida, aga just selline keelekuju nagu Vaipoolele iseloomulik, on nüüd kirjakeele aluseks. Seega pole mõtet arutada, kuivõrd õige see keel on. See on maailma viimaste emakeelena vadja keelt kõnelevate inimeste keel.

\section{Kirjandus}

Ariste, Paul 1960. Tänapäeva vadjalastest. - Etnograafiamuuseumi aastaraamat XVII, lk 203-224.

Ariste, Paul 1969. Vadja rahvakalender. Tallinn: Eesti Teaduste Akadeemia.

Ernits, Enn 2006a. Vadja keel ja kultuur ajalookatlas. - Õpetatud Eesti Seltsi aastaraamat 2004-2005. Tartu: Õpetatud Eesti Selts, lk 219-241

Ernits, Enn 2006b. Об обозначении звуков в водском языке. - Linguistica Uralica 1, c. 1-9.

Ernits, Enn 2009. Vadja haritlane Dmitri Tsvetkov. Tartu: Eesti Kirjandusmuuseumi Teaduskirjastus.

Ernits, Enn 2010a. Väärt lugemisvara vadja muistendite ja muinasjuttude näol. - Keel ja Kirjandus, lk 857-860. 
Ernits, Enn 2010b. Vadja kirjaviisist ja sõnaloomest. - ESUKA - JEFUL 2010, $1-1,1 \mathrm{k} 41-56$

Heinsoo, Heinike 2004. Investigating obsolence: Votic. - Fenno-Ugristica 26, pp. 10-16.

Heinsoo, Heinike, Kuusk, Margit 2011. Neo-renaissance and revitalization of Votic - who cares? - ESUKA - JEFUL 2011, 2-1, pp. 171-184.

Ižorin kalendar' 2012. Kuvat Harakka ja Ko, kalendar'an tekijä: Kiru, sanat: Onderen Mikitta, pri poderžke: Inkerin Kulttuuri Seura (Helsinki).

Jefimova 2010 = Ефмова, Татьяна. Vad' d'a päivüzikko 2011. - АНО Общество водской культуры. Санкт-Петербург.

Kettunen, Lauri, Posti, Lauri 1932. Näytteitä vatjan kielestä. Suomalais-Ugrilaisen Seuran Toimituksia LXVIII. Helsinki.

Kettunen, Lauri 1945. Tieteen matkamiehena: Kaksitoista ensimmaista retkeä 1907-1918. Porvoo, Helsinki: Söderström.

Konkova 2009 = Предания и сказки водского народа. Vad'd'aa rahvaа jutud ja kaazgad. Серия “Фолъклор коренных народов Ленинградской области”. Составитель и автор вступительного раздела О. И. Конькова. СанктПетербург: Музей антропологии и этнографии им. Петра Великого, (Кунсткамера). Џентр коренных народов Ленинградской области.

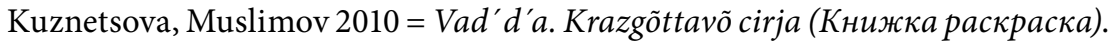
Художник Е. Кузнецова, текст: М. Муслимов, Е. Кузнецова. СанктПетербург.

Kämäräinen, Aune 2010, Vatjan kulttuuri heräilee. - Inkerin Kulttuurikanava. Inkerin kulttuuriseuran jäsenlehti 2, s. 4-6.

Kämäräinen, Aune 2011. Uudet konstit vauhdittavat vatjan kurssia. - Inkerin Kulttuurikanava. Inkerin kulttuuriseuran jäsenlehti 2, s. 4-5.

Markus, Rožanskiyi 2011 = Маркус Е. Б., Рожнский И. 2011. Сорвеменный водский язык. Тексты и грамматический очерк. Том I, II. Санкт-Петербург: Нестор-История.

Mirenkov 2002 = Мренков, Владимир 2002. Проблемы сохранения ижорского языка. - Studia Slavica Finlandesia XIX, Helsinki, c. 206-211.

Mustonen, O.A.F. 1883. Muistoonpanoja Vatjan kielestä. - Virittäjä I, s. 144188. 
Posti, Lauri, Suhonen, Seppo 1964. E. N. Setälän vatjalaismuistiinpanot. Memoria Saecularis E. N. Setälä. SUST 135.

Romanova 2010 = Романова, Яна. Водь. Краткая история еще одного исчезающего народа. - Русский Репортер 12.10.2010, 40 (168), с. 55-66.

Talve, Ilmar 1990. Matka vatjalaisiin. - Inkerin teillä. Kalevalaseuran vuosikirja 69-70. Helsinki, s. 46-66.

Tsvetkov, Dmitri 1995. Vatjan kielen Joenperän murteen sanasto. Toim. J. Laakso. Lexica Societatis Fenno-ugricae XXV. Helsinki.

Tsvetkov, Dmitri 2008. Vadja keele grammatika. Koost. ja toim. Jüri Viikberg. Tallinn: Eesti Keele Sihtasutus.

UKS 2004, 2011 = Uurali keelte sõnastik. Fenno-Ugria Asutus.

Vađđa kaazgad 2003 = Vađđa kaazgad. Воские сказки. Перевод, составление и обработка М. Муслимов. Е. Кузнецова, Е. Николаева, А. Гореликов, С. Ефимов, Т. Ефинова. Санкт-Петербург.

VP 2005 = Paul Ariste Vadja päevikud 1942-1980. Litteraria: Eesti kultuuriloo allikmaterjale 22. Koostanud, kommenteerinud ja saatesõna kirjutanud ErgoHart Västrik. Toimetanud ja järelsõna kirjutanud Peeter Olesk.

\section{Summary}

\section{Votic language - spoken and written}

The article presents observations on the language of the last present-day speakers of Votic language. There are five native Votians who live in their native villages, in Jõgõperä, Liivtšülä and Luuditsa, and still speak rather correct Votic. Historically, Votians have not had written language of their own, neither have they ever received any education in their mother tongue. The Association of Votic Culture has initiated the creation of Votic literary language in co-operation with linguists. The work has been going on for two decades, and the results are taking shape. Since 2003 the Votic literary language has been tested, mainly in translations of fairy tales 
from the Votic oral literary heritage (a collection of fairy tales in Votic and in Russian, "Vađđa kaazgad. Водские сказки" was published in 2003). A colouring book "Vad'd'a. Krazgõttavõ cirja" and Votic calendar for the year 2011 "Vad'd'a päivüzikko 2011" were published in 2010. The language courses carried out by the author of the article in 2010 and 2011 demonstrated that the aged villagers who have been educated in and and read in Cyrillic, have problems in mastering the Votic written language using Latin alphabet.

Key words: Declining language, identity, written language, dialects, formation of written language, translation, original creation. 